\title{
Marcelina Zaniewska
}

Instytut Północny im. Wojciecha Kętrzyńskiego w Olsztynie; marcelina.zaniewska@ip.olsztyn.pl

\section{Sprawozdanie z XIV konferencji naukowej pt. „Między Barokiem a Oświeceniem. Ignacy Krasicki i jego czasy”}

Report from the $14^{\text {th }}$ scientific conference "Między Barokiem a Oświeceniem. Ignacy Krasicki i jego czasy"

Bericht von der 14. wissenschaftlichen Konferenz „Między Barokiem a Oświeceniem. Ignacy Krasicki i jego czasy“

W dniach 16-18 IX 2021 r. w Lidzbarku Warmińskim odbyła się czternasta konferencja naukowa z cyklu Między Barokiem a Oświeceniem. Tegoroczne spotkanie koncentrowało się wokół postaci, twórczości i działalności biskupa Ignacego Krasickiego i czasów, w których przyszło mu żyć. Organizatorami wydarzenia byli: Instytut Północny im. Wojciecha Kętrzyńskiego, Polska Akademia Nauk Odział w Olsztynie i w Białymstoku, Towarzystwo Naukowe im. Wojciecha Kętrzyńskiego w Olsztynie oraz Muzeum Warmińskie w Lidzbarku Warmińskim i Oranżeria Kultury Miejska Biblioteka Pedagogiczna w Lidzbarku Warmińskim.

Konferencję zainaugurowano w Letnim Refektarzu na zamku w Lidzbarku Warmińskim. Zgromadzonych uczestników i gości przywitali wspólnie: kierownik Muzeum Warmińskiego - Małgorzata Jackiewicz-Garniec, dyrektor Instytutu Północnego - dr Jerzy Kiełbik oraz prezes Towarzystwa Naukowego im. Wojciecha Kętrzyńskiego w Olszynie - prof. dr hab. Stanisław Achremczyk. Podczas powitania dyrektor Kiełbik podkreślił, iż konferencja rozpoczyna serię wydarzeń przypominających o polskości Warmii w kontekście przypadającej w przyszłym roku 250. rocznicy I rozbioru Polski, wraz z którym nastąpił koniec Diecezji Warmińskiej i Dominium Warmińskiego. Ignacemu Krasickiemu przyszło być ostatnim polskim biskupem warmińskim owych czasów. 
Wśród zaproszonych gości na konferencji obecni byli m.in.: Zastępca Burmistrza Lidzbarka Warmińskiego - Piotr Łazowski, ksiądz kanonik - Roman Chudzik z kościoła pw. św. Apostołów Piotra i Pawła w Lidzbarku Warmińskim oraz Dyrektor Departamentu Kultury i Edukacji Urzędu Marszałkowskiego Województwa Warmińsko-Mazurskiego - Łukasz Łukaszewski.

Pierwszą z prelekcji wygłosiła kierownik Muzeum Warmińskiego Małgorzata Jackiewicz-Garniec, która podkreśliła, iż w czasie długiego pobytu na zamku lidzbarskim (28 lat) Ignacy Krasicki stworzył najważniejsze swoje dzieła i zmienił to miejsce w prawdziwe centrum kultury i sztuki. Prelegentka przybliżyła historię zamku oraz wskazała jakie pamiątki pozostały w tym miejscu po biskupie Krasickim. Z wystąpienia wyłonił się szczegółowy obraz Krasickiego jako mieszkańca i zarządcy zamku lidzbarskiego oraz kolekcjonera i pasjonata sztuki ogrodowej. Następnie głos zabrał prof. Stanisław Achremczyk, który wskazał liczne powody wyboru Warmii przez Krasickiego i jego przyjazdu do Lidzbarka Warmińskiego, ukazując związki rodzinne biskupa z tymi ziemiami. Profesor Achremczyk omówił również szczegółowo poglądy i wybory polityczne Krasickiego oraz drogę do objęcia przez niego diecezji warmińskiej. W ostatnim wystąpieniu tego dnia, dr hab. Magdalena Dąbrowska, prof. UW, skoncentrowała się na twórczości literackiej Krasickiego, a dokładniej na mniej znanym utworze Dziekan $z$ Badajoz oraz kwestii jego przekładu na język rosyjski, który ukazał się w 1811 r. na łamach czasopisma „Wiestnik Jewropy”.

Następnego dnia obrady prowadzono w Oranżerii Kultury w Lidzbarku Warmińskim, dawnym letnim pałacu biskupów warmińskich. Uczestników i gości przywitała dyrektor Miejskiej Biblioteki Pedagogicznej w Lidzbarku Warmińskim Anna Puszcz wraz z dyrektorem Instytutu Północnego dr. Jerzym Kiełbikiem. W pierwszej części spotkania uczestnicy wysłuchali dwóch referatów online - prof. dr hab. Andrzeja Kamieńskiego z Instytutu Historii PAN w Warszawie i prof. dr hab. Andrzeja Stroynowskiego z Akademii im. Jana Długosza w Częstochowie oraz wystąpienia stacjonarnego dr. Jacka Kowalkowskiego z Poznania. Pierwszy z prelegentów skoncentrował się na omówieniu głównych przesłanek polityki króla Prus Fryderyka II, która przyczyniła się do I rozbioru państwa polsko-litewskiego. Z kolei prof. Stroynowski zwrócił uwagę na ważne przemiany społeczeństwa polskiego w czasach stanisławowskich oraz działalność przedstawiciela ówczesnej elity politycznej, Marszałka Sejmu Franciszka Ksawerego Chomińskiego. W zamykającym pierwszy panel referacie dr Jacek Kowalkowski omówił zasługi biskupa Krasickiego na polu genealogii.

Drugą część obrad rozpoczęło wystąpienie dr Emilii Figury-Osełkowskiej z Instytutu Północnego w Olsztynie, która przybliżyła genezę, rolę oraz zawartość 
i znaczenie pisma „Monitor”, które powstało według planów opracowanych m.in. przez Ignacego Krasickiego. Autorka odniosła się również do artykułów opublikowanych przez biskupa w „Monitorze” i poruszanej w nich tematyki. Kolejna prelegentka, dr Klara Leszczyńska-Skowron z IBL PAN w Warszawie, zaprezentowała koncepcję szczęścia w twórczości Ignacego Krasickiego ukazując ją poprzez szczegółową analizę różnych sposobów rozumienia terminu „szczęście”, które można dostrzec w dorobku literackim biskupa. Do kwestii niezwiązanych z zawartością treściową, lecz szatą graficzną dzieł Krasickiego odniósł się kolejny prelegent, dr Paweł Ignaczak z warszawskiej ASP. Przedstawił on szczegółową analizę cyklu 24 ilustracji autorstwa Jana Piotra Norblina, zawartych w Myszeidzie Krasickiego. Zwieńczeniem tej części obrad był referat mgr Sylwii Szydlik, która zarysowała obraz szlachcianki widzianej oczami Krasickiego oraz podjęła próbę powiązania postaci kobiecych z dzieł biskupa z ich prawdopodobnymi, rzeczywistymi odpowiedniczkami.

Trzecia i zarazem ostatnia część obrad została poświęcona równie ciekawym zagadnieniom. Dr hab. Adam Kucharski, prof. UMK w Toruniu przybliżył kwestię dbałości Ignacego Krasickiego o zdrowie i jego licznych wyjazdów kuracyjnych do wód. Z kolei mgr Waldemar Borzestowski reprezentujący Uniwersytet Gdański skoncentrował się na pobytach biskupa w Gdańsku i ich powodach oraz przedstawił obraz ówczesnego Gdańska i jego mieszkańców. Zupełnie inny wymiar miało wystąpienie dr Katarzyny Ponińskiej, która szczegółowo zaprezentowała uroczystość koronacji cudownego wizerunku w Miedniewicach, w której uczestniczył Ignacy Krasicki. Jako ostatni wystąpił mgr Ireneusz Poniński, który przedstawił swoje rozważania nt. tekstu Krasickiego poświęconego ubiorom.

Spotkanie w Oranżerii Kultury zakończyła dyskusja i polemika nad zaprezentowanymi w tym dniu licznymi poglądami i tezami. Merytoryczną część konferencji wspólnie podsumowali i zakończyli: prof. dr hab. Stanisław Achremczyk oraz dr Emilia Figura-Osełkowska. W celu zapewnienia możliwości wysłuchania obrad szerszemu gronu odbiorców całość spotkania była transmitowana na żywo w mediach społecznościowych Instytutu Północnego im. Wojciecha Kętrzyńskiego.

Należy nadmienić, iż konferencji towarzyszyło uroczyste otwarcie wystawy Ignacy Krasicki i jego czasy, przygotowanej przez Towarzystwo Naukowe i Instytut Północny im. Wojciecha Kętrzyńskiego, dofinansowanej ze środków samorządu Warmińsko-Mazurskiego poprzez Departament Kultury i Edukacji Urzędu Marszałkowskiego Województwa Warmińsko-Mazurskiego w Olsztynie. Ekspozycja, po prezentacji w Oranżerii Kultury została przeniesiona do Muzeum Warmińskiego w Lidzbarku Warmińskim i udostępniona dla zwiedzających.

Trzeci dzień konferencji upłynął na poznaniu miejsc związanych z biskupem Krasickim. Uczestnicy zwiedzili zamek w Lidzbarku Warmińskim, następnie udali 
się do Stoczka Klasztornego oraz Galin. Przewodnikiem po świecie Krasickiego w trakcie tej podróży była dr Emilia Figura-Osełkowska z Instytutu Północnego.

Zgodnie z zapowiedzią organizatorów, jeszcze w tym roku ukaże się kolejna publikacja z cyklu Między Barokiem a Oświeceniem, w której zostaną zamieszczone referaty zaprezentowane w ramach tegorocznego, lidzbarskiego spotkania. 